\title{
Effect of Alterations in Mechanical Ventilator Settings on Pulmonary Gas Exchange in Hyaline Membrane Disease
}

\author{
E. O. R. REYNOLDS \\ From the Department of Paediatrics, University College Hospital Medical School, London
}

\begin{abstract}
Reynolds, E. O. R. (1971). Archives of Disease in Childhood, 46, 152. Effect of alterations in mechanical ventilator settings on pulmonary gas exchange in hyaline membrane disease. The effect of altering peak airway pressure, respiratory frequency, and inspiration : expiration ratio on arterial blood gas tensions, blood pressure, and calculated right-to-left shunt was investigated in 6 infants undergoing mechanical ventilation for hyaline membrane disease with a Bennet ventilator. The use of a very long inspiratory phase resulted in a large increase in $\mathrm{P}_{\mathrm{a}} \mathrm{O}_{2}$ and fall in right-to-left shunt without affecting mean arterial blood pressure.
\end{abstract}

The mortality rate of infants with hyaline membrane disease who collapse and need mechanical ventilation is high (Reynolds, 1970b). Even with the use of pure oxygen as the ventilating gas and high airway pressures, many infants die from hypoxia during the first few days of life. Other mechanically ventilated infants may survive into the second week or later, only to succumb with massive lung fibrosis which is probably caused by a combination of mechanical damage to the lungs and oxygen toxicity (Northway, Rosan, and Porter, 1967; Hawker, Reynolds, and Taghizadeh, 1967).

Very few data are available on the effect of alterations in ventilator settings on pulmonary gas exchange in infants with hyaline membrane disease (Owen-Thomas, Ulan, and Swyer, 1968; Smith et al., 1969; Harrison, Heese, and Klein, 1969). This report describes the effect of altering respiratory frequency, airway pressure, and inspiration : expiration ratio in 6 infants during mechanical ventilation

\section{Infants Studied}

Some details of the infants studied are set out in Table I. All had the clinical and radiological features of hyaline membrane disease (Reynolds, 1970a) and their general management was as previously described (Reynolds, 1970a; 1970b). The 6 infants were con-

Received 19 October 1970. secutively admitted cases who required mechanical ventilation.

Indications for mechanical ventilation. One infant (Case 1) never breathed spontaneously and was mechanically ventilated from birth. Four infants (Cases 3, 4, 5, and 6), who became apnoeic or collapsed with gasping respirations and a heart rate of less than $80 / \mathrm{min}$, failed to respond to endotracheal intubation and manual positive pressure ventilation and were therefore mechanically ventilated. Case 2 was ventilated because, though still breathing spontaneously, she developed profound hypoxaemia, hypercapnia, and acidaemia (see Table II). Oro-endotracheal tubes (Warne No. 12) were used and the ventilator was the Bennett PR2. The technique of management of the infants while undergoing mechanical ventilation has been described elsewhere (Adamson et al., 1968; Reynolds, 1970b).

\section{Methods}

Arterial blood gas tensions, $p H$, and base excess. A No. 5 French gauge Argyle catheter was introduced into the umbilical artery until a free flow of blood was obtained and then advanced a further 2 to $3 \mathrm{~cm}$. The position of the catheter tip was verified radiologically to be in the aorta at the level of the 2nd or 3rd lumbar vertebra in 3 infants. After flushing the dead space, $0.75 \mathrm{ml}$ samples of blood were taken into heparinized syringes and analysed immediately for arterial oxygen tension $\left(\mathrm{P}_{\mathrm{a}} \mathrm{O}_{2}\right)$, carbon dioxide tension $\left(\mathrm{P}_{\mathrm{a}} \mathrm{CO}_{2}\right), p \mathrm{H}$, and base excess (BE). The $\mathrm{P}_{\mathrm{a}} \mathrm{O}_{2}$ was measured at $38^{\circ} \mathrm{C}$ with a Radiometer E5044 Clarke-type oxygen 
TABLE I

Clinical Details of Infants Studied

\begin{tabular}{|c|c|c|c|c|c|}
\hline Case No. & Sex & $\begin{array}{l}\text { Birthweight } \\
\text { (g) }\end{array}$ & $\begin{array}{c}\text { Gestational } \\
\text { age (wk) }\end{array}$ & $\begin{array}{l}\text { Age at Which } \\
\text { Mechanical } \\
\text { Ventilation } \\
\text { Began (hr) }\end{array}$ & Clinical Details and Outcome \\
\hline 1 & $M$ & 1520 & 30 & Birth & $\begin{array}{l}\text { Never breathed spontaneously; died aged } 65 \text { hours; } \\
\text { necropsy: hyaline membrane disease, intraventricu- } \\
\text { lar haemorrhage }\end{array}$ \\
\hline $\begin{array}{l}2 \\
3\end{array}$ & $\begin{array}{l}\mathbf{F} \\
\mathbf{M}\end{array}$ & $\begin{array}{l}2500 \\
1530\end{array}$ & $\begin{array}{l}37 \\
32\end{array}$ & $\begin{array}{l}27 \\
23\end{array}$ & $\begin{array}{l}\text { Mechanically ventilated for } 41 \text { hours; survived } \\
\text { Mechanically ventilated for } 3 \text { days and then inter- } \\
\text { mittently for } 3 \text { weeks; operated upon for } \\
\text { hypertrophic pyloric stenosis aged } 8 \text { weeks; } \\
\text { survived }\end{array}$ \\
\hline 4 & F & 980 & 28 & 7 & $\begin{array}{l}\text { Died aged } 6 \text { days; necropsy: hyaline membrane } \\
\text { disease, intraventricular haemorrhage }\end{array}$ \\
\hline $\begin{array}{l}5 \\
6\end{array}$ & $\begin{array}{l}\mathrm{F} \\
\mathrm{F}\end{array}$ & $\begin{array}{l}1520 \\
2150\end{array}$ & $\begin{array}{l}32 \\
33\end{array}$ & $\begin{array}{l}54 \\
30\end{array}$ & $\begin{array}{l}\text { Mechanically ventilated for } 3 \text { days; survived } \\
\text { Caesarean section for severe Rhesus haemolytic } \\
\text { disease; } 2 \text { exchange transfusions; mechanically } \\
\text { ventilated for } 3 \text { days, recovering from hyaline } \\
\text { membrane disease but developed massive pulmo- } \\
\text { nary haemorrhage and hypoglycaemia, aged } 5 \text { days, } \\
\text { mechanically ventilated for a further } 2 \text { days, died } \\
\text { aged } 7 \text { days, necropsy: resolving hyaline membrane } \\
\text { disease, massive pulmonary haemorrhage }\end{array}$ \\
\hline
\end{tabular}

electrode, a correction being applied for the blood-gas difference of the electrode. $p H$ was measured at $38^{\circ} \mathrm{C}$ using the Astrup apparatus (Astrup et al., 1960), and $\mathrm{P}_{\mathrm{a}} \mathrm{CO}_{2}$ and $\mathrm{BE}$ were derived from the SiggaardAndersen nomogram after allowing for the amount of unsaturated haemoglobin (Siggaard-Andersen, 1962). Corrections for the rectal temperature of the infant were made (Severinghaus, 1965).

The inspired oxygen concentration $\left(\mathrm{F}_{1} \mathrm{O}_{2}\right)$ was measured with a Beckman D2 paramagnetic oxygen analyser. $\mathrm{Hb}$ concentration was measured by the cyanmethaemoglobin method.

Calculation of right-to-left shunt. Right-to-left shunt $\left(Q_{\mathrm{B}} / \mathrm{Q}_{\mathrm{T}}\right)$ was calculated from the shunt equation (Berggren, 1942; Comroe et al., 1955).

$$
\hat{Q}_{\mathrm{B}} / \dot{Q}_{\mathrm{T}}=\left(\mathrm{C}_{\mathrm{a}} \mathrm{O}_{2}-\mathrm{C}_{\mathrm{CO}_{2}}\right) /\left(\mathrm{C}_{\overline{\mathrm{V}} \mathrm{O}_{2}}-\mathrm{C}_{\mathrm{CO}} \mathrm{O}_{2}\right)
$$

where $\mathrm{C}_{2} \mathrm{O}_{2}=$ arterial oxygen content $(\mathrm{ml} / 100 \mathrm{ml})$, $\mathrm{C}_{\mathrm{CO}_{2}}=$ end-pulmonary capillary $\mathrm{O}_{2}$ content $(\mathrm{ml} / 100 \mathrm{ml})$, and $\mathrm{C}_{\overline{\mathrm{v}}} \mathrm{O}_{2}=$ mixed venous $\mathrm{O}_{2}$ content $(\mathrm{ml} / 100 \mathrm{ml})$.

'Ideal' alveolar oxygen tension was derived from the alveolar air equation (Riley and Cournand, 1949), assuming a respiratory exchange ratio of 0.8 (Adams, et al., 1964) and was taken to be identical with pulmonary end-capillary oxygen tension. $\mathrm{Hb}$ saturations in arterial and pulmonary end-capillary blood were obtained from the oxygen dissociation curve for fetal blood (Oh, Arcilla, and Lind, 1965), after applying a correction for $\mathrm{pH}$ (Severinghaus, 1965). In one infant (Case 6) who had had an exchange transfusion, the adult oxygen dissociation curve was used. The saturation of mixed venous blood was assumed to be $15 \%$ lower than in arterial blood (Rudolph et al., 1961). Oxygen capacity in $\mathrm{ml}$ per $100 \mathrm{ml}$ blood was obtained as $\mathrm{Hb}(\mathrm{g}) \times 1 \cdot 34$. Oxygen content in arterial, pulmonary end-capillary, and mixed venous blood was derived from $\mathrm{O}_{2}$ capacity, $\mathrm{O}_{2}$ saturation, and the solubility of $\mathrm{O}_{2}$ in blood $(0.003 \mathrm{ml} / \mathrm{mmHg}$ per $100 \mathrm{ml})$.

The validity of this method of calculation and the possible errors involved have been discussed by Strang and MacLeish (1961), Nelson et al. (1963) and Chu et al. (1967).

Arterial blood pressure. Arterial blood pressure was measured by attaching the arterial catheter directly to a Type 267BC Sanborn strain-gauge transducer connected to a Type 350-2700 Sanborn carrier preamplifier and direct writing oscillograph.

Airway pressure. Airway pressure was recorded by inserting a wide-bore needle into the ventilator tubing just proximal to the endotracheal tube and connecting it by means of a stiff plastic catheter to the pressure transducer.

Variation of ventilator settings. The ventilator was set as a pressure generator with minimal internal resistance (Mushin et al., 1969). 80-100\% oxygen, fully humidified at body temperature, was used as the ventilating gas and the following control settings were employed: peak flow-maximum; nesative pressureoff; terminal flow-off; nebulization-off. The rate, sensitivity, and expiration time controls were arranged to produce a respiratory frequency of 30 a minute at a peak airway pressure of $25 \mathrm{~cm} \mathrm{H}_{2} \mathrm{O}\left(30 \mathrm{~cm} \mathrm{H}_{2} \mathrm{O}\right.$ in Case 2) with an inspiration/expiration ratio ( $I: E$ ) of $1: 1$. After stabilization for at least 2 hours a series of between 6 and 8 predetermined alterations in respiratory frequency, peak airway pressure, and $I: E$ ratio were carried out. The order in which the alterations were made was different in each infant. Respiratory frequencies of 30 and 80 breaths a minute, peak airway pressures of 25 and $30 \mathrm{~cm} \mathrm{H}_{2} \mathrm{O}, \mathrm{I}: \mathrm{E}$ ratios of between 
TABLE II

Effects of Varying Peak Airway Pressure, Respiratory Frequency, and Inspiration : Expiration $(I$ : E) Ratio on Arterial Blood Gas Tensions, Right-to-Left Shunt $\left(\dot{Q}_{\mathrm{B}} / \dot{Q}_{\mathrm{T}}\right)$, and Mean Arterial Blood Pressure

\begin{tabular}{|c|c|c|c|c|c|c|c|c|c|c|c|}
\hline $\begin{array}{l}\text { Case } \\
\text { No. }\end{array}$ & $\begin{array}{l}\text { Age } \\
\text { (hr) }\end{array}$ & $\begin{array}{c}\text { Airway } \\
\text { Pressure } \\
\left(\mathrm{cm} \mathrm{H}_{2} \mathrm{O}\right)\end{array}$ & $\begin{array}{c}\text { Resp. } \\
\text { Frequency } \\
\text { (breaths/min) }\end{array}$ & $\begin{array}{l}\mathbf{I}: \mathbf{E} \\
\text { Ratio }\end{array}$ & $\mathrm{F}_{\mathrm{I}} \mathrm{O}_{2}$ & $\begin{array}{c}\mathbf{P a O}_{\mathbf{2}} \\
(\mathrm{mmHg})\end{array}$ & $\underset{(\mathrm{mmHg})}{\mathrm{P}_{\mathrm{aCO}}}$ & $p H$ & $\underset{(\mathrm{mEq} / 1)}{\mathrm{BE}}$ & $\dot{\mathbf{Q}}_{\mathrm{s}} / \dot{\mathbf{Q}}_{\mathbf{T}}$ & $\begin{array}{c}\text { Mean Arterial } \\
\text { Blood Pressure } \\
\text { (mmHg) }\end{array}$ \\
\hline 1 & 12 & $\begin{array}{l}25 \\
25 \\
25 \\
30 \\
25 \\
25 \\
30\end{array}$ & $\begin{array}{l}30 \\
30 \\
80 \\
30 \\
30 \\
30 \\
30\end{array}$ & $\begin{array}{l}1: 1 \\
4: 1 \\
1: 2 \\
4: 1 \\
2: 1 \\
1: 2 \\
1: 1\end{array}$ & $\begin{array}{l}0 \cdot 80 \\
0 \cdot 80 \\
0 \cdot 80 \\
0 \cdot 80 \\
0 \cdot 80 \\
0 \cdot 80 \\
0 \cdot 80\end{array}$ & $\begin{array}{r}92 \\
220 \\
35 \\
310 \\
185 \\
88 \\
117\end{array}$ & $\begin{array}{l}39 \\
40 \\
32 \\
37 \\
37 \\
37 \\
35\end{array}$ & $\begin{array}{l}7 \cdot 28 \\
7 \cdot 28 \\
7 \cdot 31 \\
7 \cdot 28 \\
7 \cdot 30 \\
7 \cdot 28 \\
7 \cdot 31\end{array}$ & $\begin{array}{l}-8 \\
-8 \\
-9 \\
-9 \\
-8 \\
-9 \\
-9\end{array}$ & $\begin{array}{l}0 \cdot 35 \\
0 \cdot 26 \\
0 \cdot 74 \\
0 \cdot 17 \\
0 \cdot 30 \\
0 \cdot 34 \\
0 \cdot 33\end{array}$ & $\begin{array}{l}28 \\
27 \\
26 \\
31 \\
31 \\
29 \\
29\end{array}$ \\
\hline 2 & $\begin{array}{l}27 \\
30\end{array}$ & $\begin{array}{l}30 \\
30 \\
30 \\
30 \\
35 \\
25 \\
30 \\
30\end{array}$ & $\begin{array}{l}\text { Spont. breathing } \\
30 \\
30 \\
80 \\
30 \\
30 \\
30 \\
30 \\
30\end{array}$ & $\begin{array}{l}2: 1 \\
1: 2 \\
1: 2 \\
4: 1 \\
4: 1 \\
1: 1 \\
3: 1 \\
1: 1\end{array}$ & $\begin{array}{l}0.95 \\
0.96 \\
0.96 \\
0.96 \\
0.96 \\
0.96 \\
0.96 \\
0.96 \\
0.96\end{array}$ & $\begin{array}{r}13 \\
112 \\
56 \\
52 \\
183 \\
222 \\
47 \\
430 \\
130 \\
62\end{array}$ & $\begin{array}{r}140 \\
46 \\
51 \\
37 \\
57 \\
53 \\
51 \\
48 \\
43\end{array}$ & $\begin{array}{l}6 \cdot 98 \\
7 \cdot 37 \\
7 \cdot 36 \\
7 \cdot 42 \\
7 \cdot 33 \\
7 \cdot 34 \\
7 \cdot 35 \\
7 \cdot 37 \\
7 \cdot 38\end{array}$ & $\begin{array}{r}-9 \\
0 \\
0 \\
-1 \\
0 \\
0 \\
0 \\
0 \\
0\end{array}$ & $\begin{array}{l}0.36 \\
0.59 \\
0.60 \\
0.26 \\
0.25 \\
0.66 \\
0 \cdot 32 \\
0.55\end{array}$ & $\begin{array}{l}30 \\
31 \\
32 \\
33 \\
32 \\
33 \\
34 \\
34 \\
34\end{array}$ \\
\hline 3 & $\begin{array}{l}23 \\
32\end{array}$ & $\begin{array}{l}25 \\
25 \\
25 \\
30 \\
25 \\
25 \\
30\end{array}$ & \begin{tabular}{|c|} 
Spont. breathing \\
80 \\
30 \\
30 \\
30 \\
30 \\
30 \\
30
\end{tabular} & $\begin{array}{l}1: 2 \\
1:: 1 \\
4: 1 \\
4: 1 \\
1: 2 \\
2: 1 \\
1: 1\end{array}$ & $\begin{array}{l}0.98 \\
0.96 \\
0.96 \\
0.96 \\
0.96 \\
0.96 \\
0.96 \\
0.97\end{array}$ & $\begin{array}{r}23 \\
44 \\
54 \\
86 \\
106 \\
60 \\
81 \\
85\end{array}$ & $\begin{array}{r}150 \\
76 \\
72 \\
82 \\
84 \\
85 \\
85 \\
84\end{array}$ & $\begin{array}{l}6 \cdot 81 \\
7 \cdot 23 \\
7 \cdot 23 \\
7 \cdot 22 \\
7 \cdot 22 \\
7 \cdot 23 \\
7 \cdot 21 \\
7 \cdot 23\end{array}$ & $\begin{array}{r}-13 \\
-1 \\
-2 \\
-1 \\
0 \\
-2 \\
0 \\
+1\end{array}$ & $\begin{array}{l}0.76 \\
0.67 \\
0.58 \\
0.41 \\
0.39 \\
0.53 \\
0.43 \\
0.41\end{array}$ & $\begin{array}{l}- \\
37 \\
39 \\
40 \\
40 \\
38 \\
38 \\
38\end{array}$ \\
\hline 4 & $\begin{array}{r}6 \\
21\end{array}$ & $\begin{array}{l}25 \\
25 \\
25 \\
25 \\
30 \\
30\end{array}$ & \begin{tabular}{|c|} 
Spont. breathing \\
30 \\
80 \\
30 \\
30 \\
30 \\
30
\end{tabular} & $\begin{array}{l}1: 1 \\
1: 2 \\
4: 1 \\
1: 2 \\
1: 1 \\
4: 1\end{array}$ & $\begin{array}{l}0.90 \\
1.00 \\
0.99 \\
1.00 \\
0.99 \\
1.00 \\
1.00\end{array}$ & $\begin{array}{r}36 \\
121 \\
49 \\
215 \\
107 \\
142 \\
278\end{array}$ & $\begin{array}{l}50 \\
38 \\
32 \\
37 \\
35 \\
33 \\
40\end{array}$ & $\begin{array}{l}7 \cdot 07 \\
7 \cdot 53 \\
7 \cdot 56 \\
7 \cdot 52 \\
7 \cdot 53 \\
7 \cdot 56 \\
7 \cdot 52\end{array}$ & $\begin{array}{l}-9 \\
+9 \\
+8 \\
+8 \\
+8 \\
+9 \\
+9\end{array}$ & $\begin{array}{l}0.68 \\
0.43 \\
0.74 \\
0.37 \\
0.47 \\
0.42 \\
0.33\end{array}$ & $\begin{array}{l}- \\
33 \\
32 \\
34 \\
35 \\
36 \\
35\end{array}$ \\
\hline 5 & $\begin{array}{l}54 \\
58\end{array}$ & $\begin{array}{l}30 \\
25 \\
25 \\
30 \\
25 \\
25 \\
25\end{array}$ & \begin{tabular}{|c|} 
Spont. breathing \\
30 \\
30 \\
30 \\
30 \\
80 \\
30 \\
30
\end{tabular} & $\begin{array}{l}1: 1 \\
4: 1 \\
1: 2 \\
4: 1 \\
1: 2 \\
2:: 1 \\
1: 1\end{array}$ & $\begin{array}{l}0.96 \\
0.97 \\
0.96 \\
0.96 \\
0.97 \\
0.97 \\
0.97 \\
0.97\end{array}$ & $\begin{array}{r}55 \\
114 \\
126 \\
65 \\
194 \\
61 \\
143 \\
91\end{array}$ & $\begin{array}{r}150 \\
71 \\
75 \\
72 \\
77 \\
65 \\
73 \\
74\end{array}$ & $\begin{array}{l}6 \cdot 96 \\
7 \cdot 28 \\
7 \cdot 27 \\
7 \cdot 28 \\
7 \cdot 25 \\
7 \cdot 29 \\
7 \cdot 26 \\
7 \cdot 26\end{array}$ & $\begin{array}{l}-2 \\
+1 \\
+2 \\
+2 \\
+1 \\
+1 \\
+1 \\
+2\end{array}$ & $\begin{array}{l}0 \cdot 46 \\
0 \cdot 40 \\
0 \cdot 39 \\
0.52 \\
0 \cdot 34 \\
0.55 \\
0 \cdot 39 \\
0.41\end{array}$ & $\begin{array}{l} \\
41 \\
40 \\
38 \\
38 \\
36 \\
36 \\
36\end{array}$ \\
\hline 6 & $\begin{array}{l}29 \\
32\end{array}$ & $\begin{array}{l}25 \\
25 \\
30 \\
25 \\
30 \\
25 \\
25\end{array}$ & \begin{tabular}{|c|} 
ppont. breathing $\star$ \\
80 \\
30 \\
30 \\
30 \\
30 \\
30 \\
30
\end{tabular} & $\begin{array}{l:l}1 & : 2 \\
1 & : 1 \\
4 & : 1 \\
1 & : 2 \\
1 & : 1 \\
2 & : 1 \\
4 & : 1\end{array}$ & $\begin{array}{l}0.92 \\
0.96 \\
0.97 \\
0.96 \\
0.96 \\
0.96 \\
0.95 \\
0.96\end{array}$ & $\begin{array}{r}31 \\
50 \\
81 \\
285 \\
105 \\
145 \\
193 \\
244\end{array}$ & $\begin{array}{r}134 \\
57 \\
69 \\
69 \\
69 \\
60 \\
71 \\
65\end{array}$ & $\begin{array}{l}7 \cdot 07 \\
7 \cdot 34 \\
7 \cdot 31 \\
7 \cdot 31 \\
7 \cdot 32 \\
7 \cdot 33 \\
7 \cdot 31 \\
7 \cdot 32\end{array}$ & $\begin{array}{l}-1 \\
+2 \\
+3 \\
+3 \\
+3 \\
+2 \\
+2 \\
+2\end{array}$ & $\begin{array}{l}0.72 \\
0.66 \\
0 \cdot 49 \\
0.27 \\
0 \cdot 42 \\
0 \cdot 39 \\
0.38 \\
0.31\end{array}$ & $\begin{array}{l}- \\
46 \\
45 \\
49 \\
47 \\
46 \\
48 \\
49\end{array}$ \\
\hline
\end{tabular}

*Last values obtained while the infants were still breathing spontaneously.

$1: 2$ and $4: 1$, and the effect of a $5 \mathrm{~cm} \mathrm{H}_{2} \mathrm{O}$ increment of peak airway pressure at an $\mathrm{I}: \mathrm{E}$ ratio of $4: 1$ were investigated. The pressure, rate, expiration time, and sensitivity controls were used to produce the alterations, the other controls remaining untouched. Two airway pressure recordings are illustrated in Fig. 1. After each alteration in ventilator settings the lungs were held statically inflated for 3 to 4 seconds, and 15 minutes were then allowed to elapse before readings of arterial blood pressure, and samples of arterial blood for analysis, were taken.

No steps were taken to control the attempts which were occasionally made by the infants to breathe against the ventilator.

Statistical methods. Student's t test was used to determine whether, between each pair of ventilator settings, the mean of the differences between readings 


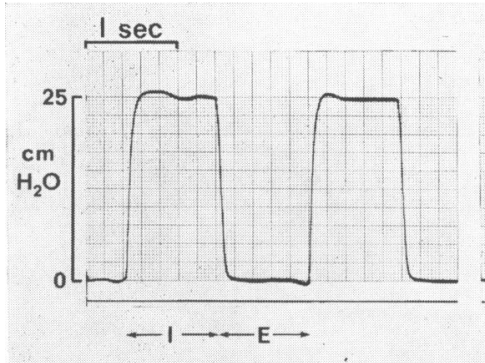

a

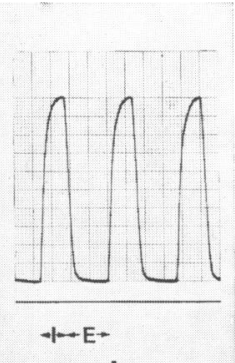

b
FIG. 1.-Airway pressure recordings in Case 5. (a) Frequency 30/min, I: E ratio $1: 1$. (b) Frequency $80 / \mathrm{min}$, $I:$ E ratio $1: 2$.

of $\mathrm{P}_{\mathrm{a}} \mathrm{O}_{2}, \mathrm{P}_{\mathrm{a}} \mathrm{CO}_{2}, \dot{\mathrm{Q}}_{\mathrm{B}} / \dot{Q}_{\mathrm{T}}$, and mean arterial blood pressure was significantly different from zero.

\section{Results}

Table II shows the age after birth at which the study was performed and the results obtained in

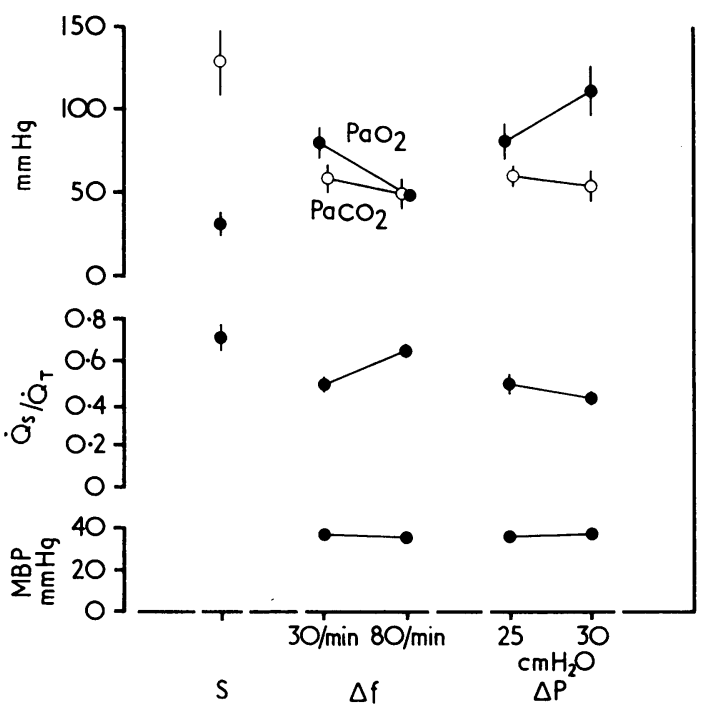

FIG. 2.-Effect of varying respiratory frequency, and peak airway pressure on arterial oxygen tension $\left(\mathrm{P}_{\mathrm{a}} \mathrm{O}_{2}\right)$, carbon dioxide tension $\left(\mathrm{P}_{\mathrm{a}} \mathrm{CO}_{2}\right)$, calculated right-to-left shunt $\left(\dot{\mathrm{Q}}_{\mathrm{s}} / \mathrm{Q}_{\mathrm{T}}\right)$, and mean arterial blood pressure $(M B P)$. In the uppermost part of the diagram $=P_{\mathrm{a}} \mathrm{O}_{2}$ and $\mathrm{O}=P_{\mathrm{a}} \mathrm{CO}_{2}$. Mean values $\pm 1 S E M$ are shown (for actual data see Table $I I) . \quad S=$ the last values obtained during spontaneous breathing. $\triangle f=$ values at respiratory frequencies of $30 / \mathrm{min}$ and $80 / \mathrm{min}$; peak airway pressure constant at $25 \mathrm{~cm} \mathrm{H}_{2} \mathrm{O}, \mathrm{I}: \mathrm{E}$ ratio constant at $1: 2 . \triangle P=$ values at peak airway pressures of $25 \mathrm{~cm}$ $\mathrm{H}_{2} \mathrm{O}$ and $30 \mathrm{~cm} \mathrm{H}_{2} \mathrm{O}$; respiratory frequency constant at $30 / \min , I: E$ ratio constant at $1: 2$. each infant for peak airway pressure, respiratory frequency, $\mathrm{I}: \mathrm{E}$ ratio, $\mathrm{F}_{1} \mathrm{O}_{2}, \mathrm{P}_{\mathrm{a}} \mathrm{O}_{2}, \mathrm{P}_{\mathrm{a}} \mathrm{CO}_{2}, p \mathrm{H}$, $\mathrm{BE}, \dot{\mathrm{Q}}_{\mathrm{B}} / \dot{\mathrm{Q}}_{\mathrm{T}}$, and mean arterial blood pressure (MBP), arranged in the order in which the observations were made.

Fig. 2 and 3 show data obtained from the last blood sample taken while the infant was still breathing spontaneously, and data obtained during mechanical ventilation showing the effect of altering respiratory frequency, peak airway pressure, and $\mathrm{I}: \mathrm{E}$ ratio on $\mathrm{P}_{\mathrm{a}} \mathrm{O}_{2}, \mathrm{P}_{\mathrm{a}} \mathrm{CO}_{2}, \dot{\mathrm{Q}}_{\mathrm{g}} / \dot{\mathrm{Q}}_{\mathrm{T}}$, and MBP.

Respiratory frequency. (Fig. 2, $\triangle \mathrm{f}$ ). At an $I$ : E ratio of $1: 2$ and a peak airway pressure of $25 \mathrm{~cm} \mathrm{H}_{2} \mathrm{O}, \mathrm{P}_{\mathrm{a}} \mathrm{O}_{2}$ was lower at a respiratory frequency of 80 breaths a minute than at 30 breaths a minute (mean difference between paired readings $31.5 \mathrm{mmHg} \pm 10.7 \mathrm{SEM}, \mathrm{N}=6, \mathrm{P}<0.025)$. $\mathrm{P}_{\mathrm{a}} \mathrm{CO}_{2}$ was also lower at the faster frequency (mean diff. $8.3 \pm 1 \cdot 7 \mathrm{mmHg}, \mathrm{N}=6, \quad \mathrm{P}<0.0025)$. $\dot{\mathrm{Q}}_{\mathrm{B}} / \dot{\mathrm{Q}}_{\mathrm{T}}$ was less at the slower frequency (mean diff. $0 \cdot 18 \pm 0 \cdot 06, \mathrm{~N}=6, \mathrm{P}<0.025)$.

Peak airway pressure. At a respiratory frequency of 30 breaths a minute and an $\mathrm{I}: \mathrm{E}$ ratio of $1: 1$ (Fig. 2, $\triangle \mathrm{P}$ ), $\mathrm{P}_{\mathrm{a}} \mathrm{O}_{2}$ was higher at an

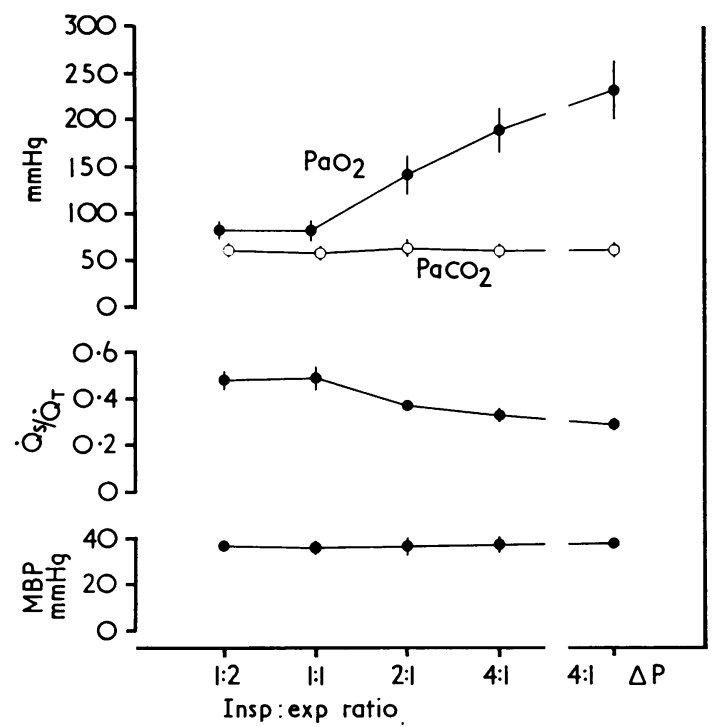

FIG. 3.-Effect of altering $I: E$ ratio on arterial blood gas tensions, right-to-left shunt, and mean arterial blood pressure (abbreviations as in Fig. 1). Peak airway pressure constant at $25 \mathrm{~cm} \mathrm{H}_{2} \mathrm{O}$ in 5 infants and $30 \mathrm{~cm}$ $\mathrm{H}_{2} \mathrm{O}$ in one. Respiratory frequency constant at 30/min.

$4: 1, \triangle P$ shows the effect of a $5 \mathrm{~cm}$ increment in airway pressure at an $I: E$ ratio of $4: 1$. 

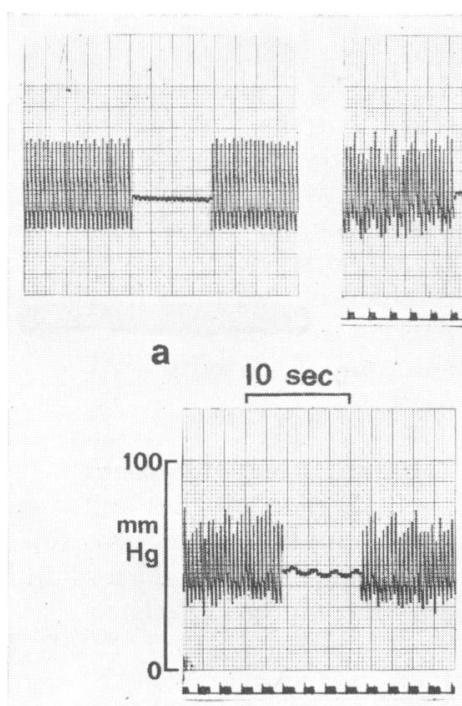

d

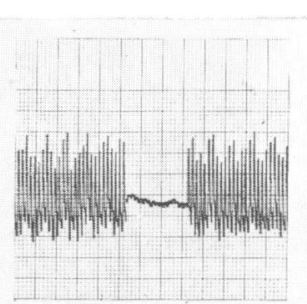

b

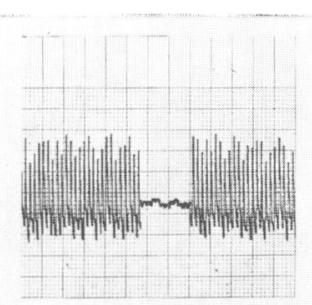

$m-m-m b-m-m-m b$

C airway pressure of $30 \mathrm{~cm} \mathrm{H}_{2} \mathrm{O}$ than at $25 \mathrm{~cm} \mathrm{H}_{2} \mathrm{O}$ (mean diff. $29 \cdot 8 \pm 7 \cdot 1 \mathrm{mmHg}, \mathrm{N}=6, \mathrm{P}<0.005$ ); $\dot{Q}_{\mathrm{B}} / \dot{Q}_{\mathrm{T}}$ was less at the higher pressure (mean diff. $0.07 \pm 0.03, \mathrm{~N}=6, \mathrm{P}<0.05)$.

A $5 \mathrm{~cm} \mathrm{H}_{2} \mathrm{O}$ increment in peak airway pressure at an $I: E$ ratio of $4: 1$ (Fig. $3, \triangle P$ ) also caused an increase in $\mathrm{P}_{\mathrm{a}} \mathrm{O}_{2}$ (mean diff. $53.3 \pm 10 \cdot 2 \mathrm{mmHg}$, $\mathrm{N}=6, \mathrm{P}<0.025$ ) and a fall in $\dot{\mathrm{Q}}_{\mathrm{B}} / \dot{\mathrm{Q}}_{\mathrm{T}}$ (mean diff. $0.04 \pm 0.01, N=6, P<0.025)$.

Inspiration : expiration ratio. (Fig. 3 ). The peak airway pressure was constant at $25 \mathrm{~cm}$ $\mathrm{H}_{2} \mathrm{O}$ in Cases $1,3,4,5$, and 6 and constant at $30 \mathrm{~cm} \mathrm{H}_{2} \mathrm{O}$ in Case 2; the respiratory frequency was always 30 breaths a minute. No significant differences were found between an $I: E$ ratio of $1: 2$ and one of $1: 1$, but as $I: E$ increased from $1: 1$ to $2: 1$ and $4: 1$, a significant increase in $\mathrm{P}_{\mathrm{a}} \mathrm{O}_{2}$ occurred (mean diff. $1: 1$ vs. $2: 1,69 \cdot 2$ $\pm 14.6 \mathrm{mmHg}, \mathrm{N}=5, \mathrm{P}<0.005 ; 1: 1$ vs. $4: 1$, $97.3 \pm 21.9 \mathrm{mmHg}, \mathrm{N}=6, \mathrm{P}<0.005$; the increase in $\mathrm{P}_{\mathrm{a}} \mathrm{O}_{2}$ between $2: 1$ and $4: 1$ did not reach statistical significance-mean difference $28 \cdot 8$ $\pm 15.7 \mathrm{mmHg}, \mathrm{N}=5,0.05<\mathrm{P}<0.1)$.

As $I$ : $E$ increased from $1: 1$ to $4: 1, \dot{Q}_{\mathrm{B}} / \dot{Q}_{\mathrm{T}}$ progressively fell (mean diff. $1: 1$ vs. $2: 1,0 \cdot 13$ $\pm 0.05, \mathrm{~N}=5, \mathrm{P}<0.05 ; 1: 1$ vs. $4: 1,0.15$ $\pm 0.05, \mathrm{~N}=6, \mathrm{P}<0.025 ; 2: 1$ vs. $4: 1,0.04$ $\pm 0.02, N=5, P<0.025$ ).

No other significant differences were found; in particular the mean arterial blood pressure did not alter during the investigation, and $\mathrm{P}_{\mathrm{a}} \mathrm{CO}_{2}$ did not change except with respiratory frequency.

Fig. 4 shows blood pressure recordings obtained in Case 6.

\section{Discussion}

When mechanical ventilation was first used in our unit for the treatment of infants with hyaline membrane disease, fast respiratory frequencies of up to 80 breaths/min were employed (Adamson et al., 1968). The reasons for choosing a fast frequency were twofold: firstly, the infants had been breathing spontaneously at least as fast as 80 breaths/min before collapsing, and it was found that fighting against the machine was less likely to occur when mechanical ventilation was initiated at a fast frequency than when a slow frequency was used. Secondly, since lung compliance is grossly reduced in hyaline membrane disease, it was thought that adequate gas exchange should be attainable at a lower peak airway pressure if a fast frequency 
was selected. With this type of ventilation (Fig. 1b) little difficulty was experienced in keeping the $\mathrm{P}_{\mathrm{a}} \mathrm{CO}_{2}$ at a normal level but adequate arterial oxygenation was often impossible to achieve.

With further experience we found that an increase in $\mathrm{P}_{\mathrm{a}} \mathrm{O}_{2}$ followed slowing the respiratory frequency, or increasing peak airway pressure. In 1969, Smith et al., using methods similar to ours proved that slow respiratory frequencies and high peak airway pressures caused an improvement in $\mathrm{P}_{\mathrm{a}} \mathrm{O}_{2}$. The data presented in Fig. 2 confirm their conclusions and also show that the $\mathrm{P}_{\mathrm{a}} \mathrm{CO}_{2}$, as well as the $\mathrm{P}_{\mathrm{a}} \mathrm{O}_{2}$, is higher at a frequency of $30 / \mathrm{min}$ than at a frequency of $80 / \mathrm{min}$.

Inspiration : expiration ratio. Several lines of reasoning suggested that the use of a long inspiratory phase on the ventilator might improve arterial oxygenation. Firstly, because the air-liquid interface in the alveoli is deficient in pulmonary surfactant during the acute phase of hyaline membrane disease (Avery and Mead, 1959), the alveoli will probably collapse completely during expiration and only reopen during inspiration when a transpulmonary pressure greater than about 15-20 $\mathrm{cm} \mathrm{H}_{2} \mathrm{O}$ has been generated (Clements, 1962; Reynolds and Strang, 1966). Secondly, observing the exposed visceral pleural surface of the lungs of immature, surfactant deficient lambs with hyaline membrane diseases showed that the alveoli were open only during peak inspiration (Normand et al., 1968). Thirdly, it appeared possible that the improvement in $\mathrm{P}_{\mathrm{a}} \mathrm{O}_{2}$, caused in infants with hyaline membrane disease by slowing the respiratory frequency and increasing peak airway pressure, was due to improved alveolar inflation. It was therefore reasoned that if the alveoli could be held open for a longer proportion of each breath, oxygen uptake might be improved. There are two possible ways in which the alveoli could be held open, by applying an end-expiratory pressure with the ventilator, or by increasing the inspiration : expiration ratio. The latter alternative was chosen because it would be difficult to apply an end-expiratory pressure with a Bennett ventilator, and also because interference with venous return to the heart should be less if intrathoracic pressure is allowed to return to zero for at least part of the ventilatory cycle.

The data presented in Fig. 3 show a striking and progressive increase in $\mathrm{P}_{\mathrm{a}} \mathrm{O}_{2}$ and fall in calculated right-to-left shunt with increasing $\mathrm{I}: \mathrm{E}$ ratio beyond $1: 1$. Shunting, which is the principal cause of hypoxaemia during the acute phase of hyaline membrane disease, is thought to occur mainly because interference with pulmonary gas exchange and atelectasis cause constriction of pulmonary blood vessels and an increase in pulmonary vascular resistance: as $\mathrm{P}_{\mathrm{a}} \mathrm{O}_{2}$ falls and pulmonary vascular resistance rises the foramen ovale and ductus arteriosus reopen and blood passes from the right side of the heart to the aorta without traversing the lungs (Cook et al., 1963; Reynolds and Strang, 1966; Strang, 1966). Intrapulmonary shunts, in which blood flows past atelectatic air-spaces, may also be present (Wallgren et al., 1967; Murdock et al., 1970). The increasing $\mathrm{P}_{\mathrm{a}} \mathrm{O}_{2}$ and decreasing right-to-left shunt found in this investigation caused by increasing the $\mathrm{I}: \mathrm{E}$ ratio can be ascribed to the release of pulmonary vasoconstrictor tone, to the mechanical effects of alveolar inflation in dilating pulmonary blood vessels (Howell et al., 1961; Cassin et al., 1964), and to the oxygenation of blood passing through intrapulmonary shunts.

No alterations in mean arterial blood pressure occurred during the investigation, even with peak airway pressures of $30-35 \mathrm{~cm} \mathrm{H}_{2} \mathrm{O}$ and an $\mathrm{I}: \mathrm{E}$ ratio of $4: 1$, though oscillations of blood pressure became somewhat greater when very long inspiratory phases were used (Fig. 4). With normal lungs a ventilator pressure wave of this type would probably produce impairment of venous return to the heart and a fall in arterial blood pressure (Morgan et al., 1966; Mushin et al., 1969). In hyaline membrane disease the retractile force of the surfactant-deficient air liquid interface should prevent comparatively high intra-alveolar pressures from being transmitted to the intrapleural space.

Implications for ventilator management of hyaline membrane disease. This study was performed with a positive pressure-generating flow (or time) cycled ventilator with minimal internal resistance, capable of holding a plateau of peak airway pressure (Fig. 1a). The results of the investigation cannot be applied to other ventilators, particularly constant flow generators. Using a flow generator, which does not produce a plateau of pressure, Harrison et al. (1969) found that the $\mathrm{P}_{\mathrm{a}} \mathrm{O}_{2}$ improved when fast respiratory frequencies were used, presumably because the alveoli were only open briefly during peak inspiration.

With a ventilator producing pressure waves similar to those used in this study some tentative conclusions can be drawn about the settings to be employed during the acute phase of the illness. It seems reasonable initially to use $100 \% \mathrm{O}_{2}$ as the ventilating gas, a respiratory frequency of about $30 \mathrm{breaths} / \mathrm{min}$, a peak airway pressure of $25 \mathrm{~cm}$ 
$\mathrm{H}_{2} \mathrm{O}$ and an inspiration : expiration ratio of $1: 1$.

If the $\mathrm{P}_{\mathrm{a}} \mathrm{CO}_{2}$ is too high it can be reduced by increasing the respiratory frequency, but this will also reduce the $\mathrm{P}_{\mathrm{a}} \mathrm{O}_{2}$.

If adequate arterial oxygenation is not achieved, the $\mathrm{P}_{\mathrm{a}} \mathrm{O}_{2}$ can be improved either by increasing peak airway pressure or by increasing inspiration : expiration ratio. Because high airway pressures may be partly responsible for initiating fibrotic lesions in the lungs (Hawker et al., 1967) and may cause a pneumothorax, it might be safer to increase inspiration : expiration ratio. It must be emphasized that infants have not yet been ventilated with very long inspiratory phases for longer than the brief periods employed in this investigation; if this approach is used arterial, and ideally central venous and intraoesophageal, pressure should be measured. If mechanical ventilation with a long inspiratory phase proves safe for long-term ventilation, it might be possible to reduce the inspired oxygen concentration to a level where pulmonary oxygen toxicity becomes unlikely.

It would probably be dangerous to use long inspiratory phases once recovery has started, on about the 3 rd to 5th day. Pulmonary surfactant is found in the lungs of infants dying from hyaline membrane disease if they have survived longer than 5 days (Hawker et al., 1967); and widespread uneven airways obstruction is present (Adamson et al., 1969). A long inspiratory phase during recovery would almost certainly cause circulatory embarrassment and also favour air trapping. At this stage of the illness it would probably be preferable to use an inspiration : expiration ratio of about $1: 2$.

I am grateful to Professor L. B. Strang for helpful comments, the Wellcome Trust for financial assistance, Mr. F. Talley of Vickers Medical for help in servicing the ventilators, and Mr. C. M. J. Bright for technical assistance.

\section{REFERENCES}

Adams, F. H., Fujiwara, T., Spears, R., and Hodgman, J. (1964). Gaseous metabolism in premature infants at $32-34^{\circ} \mathrm{C}$ ambient temperature. Pediatrics, 33, 75.

Adamson, T. M., Collins, L. M., Dehan, M., Hawker, J. M. Reynolds, E. O. R., and Strang, L. B. (1968). Mechanical ventilation in newborn infants with respiratory failure. Lancet, $2,227$.

Adamson, T. M., Hawker, J. M., Reynolds, E. O. R., and Shaw, J. L. (1969). Hypoxemia during recovery from severe hyaline membrane disease. Pediatrics, 44, 168.

Astrup, P., Jørgensen, K., Siggaard-Andersen, O., and Engel, K. (1960). The acid-base metabolism: a new approach. Lancet, $1,1035$.

Avery, M. E., and Mead, J. (1959). Surface properties in relation to atelectasis and hyaline membrane disease. American Fournal of Diseases of Children, 97, 517.
Berggren, S. M. (1942). Oxygen deficit of arterial blood caused by non-ventilating parts of lung. Acta Physiologica Scandinavica, 4, suppl. II.

Cassin, S., Dawes, G. S., Mott, J. C., Ross, B. B., and Strang, L. B. (1964). The vascular resistance of the foetal and newly ventilated lung of the lamb. Fournal of Physiology, 171, 61 .

Chu, J., Clements, J. A., Cotton, E. K., Klaus, M. H., Sweet, A. Y. and Tooley, W. H. (1967). Neonatal pulmonary ischemia. I. Clinical and physiological studies. Pediatrics, 40, 709.

Clements, J. A. (1962). Surface phenomena in relation to pulmonary functions (sixth Bowditch lecture). Physiologist, 5, 11 .

Comroe, J. H., Jr., Foster, R. E., Dubois, A. B., Briscoe, W. A., and Carlsen, E. (1955). The Lung, p. 187. Year Book Medical Publishers, Chicago.

Cook, C. D., Drinker, P. A., Jacobson, H. N., Levison, H., and Strang, L. B. (1963). Control of pulmonary blood flow in the foetal and newly born lamb. Fournal of Physiology, 169, 10.

Harrison, V. C., Heese, H. de V., and Klein, M. (1969). The effects of intermittent positive pressure ventilation on lung function in hyaline membrane disease. British fournal of Anaesthesia, 41, 908.

Hawker, J. M., Reynolds, E. O. R., and Taghizadeh, A. (1967). Pulmonary surface tension and pathological changes in infants dying after respirator treatment for severe hyaline membrane disease. Lancet, 2, 75.

Howell, J. B. L., Permutt, S., Proctor, D. F., and Riley, R. L. (1961). Effect of inflation of the lung on different parts of pulmonary vascular bed. Fournal of Applied Physiology, 16, 71.

Morgan, B. C., Martin, W. E., Hornbein, T. F., Crawford, W. E., and Guntheroth, W. G. (1966). Hemodynamic effects of intermittent positive pressure respiration. Anaesthesiology, 27, 584 .

Murdock, A. I., Kidd, B. S. L., Llewellyn, M. A., Reid, M. Mc.C., and Swyer, P. R. (1970). Intrapulmonary venous admixture in the respiratory distress syndrome. Biology of the Neonate, 15,1 .

Mushin, W. W., Rendell-Baker, L., Thompson, P. W., and Mapleson, W. W. (1969). Automatic Ventilation of the Lungs. 2nd ed., pp. 9, 70, and 349. Blackwell, Oxford and Edinburgh.

Nelson, N. M., Prod'hom, L. S., Cherry, R. B., Lipsitz, P. J., and Smith, C. A. (1963). Pulmonary function in the newborn infant: the alveolar-arterial oxygen gradient. Fournal of Applied Physiology, 18, 534.

Normand, I. C. S., Reynolds, E. O. R., Strang, L. B., and Wigglesworth, J. S. (1968). Flow and protein concentration of lymph from lungs of lambs developing hyaline membrane disease. Archives of Disease in Childhood, 43, 334.

Northway, W. H., Jr., Rosan, R. C., and Porter, D. Y. (1967) Pulmonary disease following respirator therapy of hyalinemembrane disease; bronchopulmonary dysplasia. New England Fournal of Medicine, 276, 357.

Oh, W., Arcilla, R. A., and Lind, J. (1965). In vivo blood oxygen dissociation curve of newborn infants. Biologia Neonatorum, 8, 241.

Owen-Thomas, J. B., Ulan, O. A, and Swyer, P. R. (1968). The effect of varying inspiratory gas flow rate on arterial oxygenation during IPPV in the respiratory distress syndrome. British Fournal of Anaesthesia, 40, 493.

Reynolds, E. O. R. (1970a). Hyaline membrane disease. American fournal of Obstetrics and Gynecology, 106, 780.

Reynolds, E. O. R. (1970b). Indications for mechanical ventilation in infants with hyaline membrane disease. Pediatrics, 46, 193.

Reynolds, E. O. R., and Strang, L. B. (1966). Alveolar surface properties of the lung in the newborn. British Medical Bulletin, 22, 79.

Riley, R. L., and Cournand, A. (1949). 'Ideal' alveolar air and the analysis of ventilation-perfusion relationships in the lungs. Fournal of Applied Physiology, 1, 825.

Rudolph, A. M., Drorbaugh, J. E., Auld, P. A. M., Rudolph, A. J., Nadas, A. S., Smith, C. A., and Hubbell, J. P. (1961). Studies on the circulation in the neonatal period: the circulation in the respiratory distress syndrome. Pediatrics, 27, 551.

Severinghaus, J. W. (1965). Blood gas concentrations. Handbook of Physiology, Section 3, Respiration, vol. 2, p. 1475 . Ed. by W. O. Fenn and H. Rahn. American Physiological Society, Washington, D.C.

Siggaard-Andersen, O. (1962). The pH-log $\mathrm{PcO}_{2}$ blood acid-base nomogram revised. Scandinavian fournal of Clinical and Laboratory Investigation, 14, 598. 
Smith, P. C., Daily, W. J. R., Fletcher, G., Meyer, H. B. P., and Taylor, G.. (1969). Mechanical ventilation of newborn infants. I. The effect of rate and pressure on arterial oxygenation of infants with respiratory distress syndrome. Pediatric Research, 3, 244.

Strang, L. B. (1966). The pulmonary circulation in the respiratory distress syndrome. Pediatric Clinics of North America, 13, 693. Strang, L. B., and MacLeish, M. H. (1961). Ventilatory failure and right-to-left shunt in newborn infants with respiratory distress. Pediatrics, 28, 17.
Wallgren, G., Hanson, J. S., Tabakin, B. S., Räihä, N., and Vapaavuori, E. (1967). Quantitative studies of the human neonatal circulation. V. Hemodynamic findings in premature infants with and without respiratory distress. Acta Paediatrica, suppl. 179, 69.

Correspondence to author, Department of Paediatrics, University College Hospital, Gower Street, London W.C.1. 